\title{
Christian ministry and theological education as instruments for economic survival in Africa
}

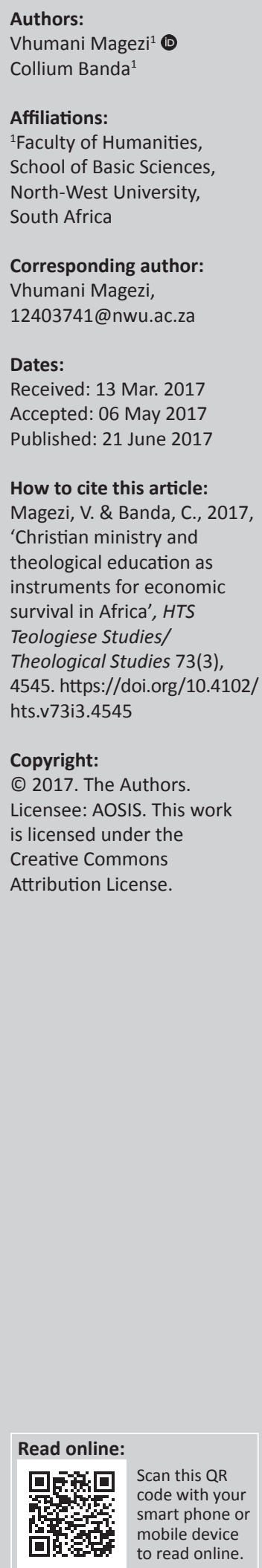

There is a conflict over whether Christian ministry and theological education should be pursued with an expectation for economic survival. The rise of Christian ministry practice emphasising wealth and prosperity has heightened commodification of the Christian ministry. Church ministry and theological education are being used as instruments for economic profit. The link between theological education and Christian ministry, among other things, is that church practices and ministry expressions reflect the underlying theology. In such a situation, this article reflects on the following questions: How are Christian ministry and its undergirding theology being utilised as instruments of economic prosperity in Africa? What is the theological education approach that is employed to support this ministry approach? The article attempts to establish an understanding of ministerial practise that has biblically and theologically informed views of material wealth. It begins by examining the traditional missionary model of ministry as a sacrificial act and responses by African clergy. This is followed by examination of the development of the view of ministry as a means of economic survival and commodification of ministry and theological education in Africa. It concludes by providing an evaluation and proposing a way forward.

\section{Introduction}

The rise of Christian ministerial practices emphasising wealth and prosperity ultimately raises questions about the appropriateness of using church ministry and theological education as instruments for economic survival. Africa continues to see an increase in many wealthy church pastors and prophets who preach the gospel of material prosperity (Angel 2013; Asamoah-Gyadu 2009; Chitando, Gunda \& Kügler 2013; Marshall 2009). In Zimbabwe, this emphasis on material prosperity and their amassing of personal wealth from their churches has left critical and cynical observers contemptuously speaking of 'gospelprenuers' (Chitando et al. 2013:9; News24 2015), to bemoan the turning of the Christian gospel into a commodity that can become a form of lucrative entrepreneurship. Consequently, the image of church ministers has radically shifted from the traditional anti-materialist and heavenly focused clergy who lived frugally, to the materialistic and glamorous clergy who invest in stock markets and amass enough wealth to contend for listing among the world's richest business people (The Herald 2014). Unlike the traditional model where to be a pastor amounted to renouncing the world to pursue a heavenly spiritual calling, the entrepreneurial model presents true spirituality and ministry as are authenticated by socioeconomic progress. While the entrepreneurial model may appear in Africa as a new phenomenon, its modern origins trace to the 1950s American mega revival evangelists who built their mega ministries not just 'on gifts alone but on the financial and organisational skills of the evangelists' (Harrell 1975:106). In the 15th century, John Calvin severely condemned priests who corrupted the diaconate by turning it into 'a licence to rob and steal' (Institutes 4.5.16), while the Apostle Paul condemned those who preached the gospel for sordid gains. This highlights that gospelpreneurship is not a new phenomenon, although from time to time it exhibits new characteristics.

Furthermore, in poor African contexts such as Zimbabwe, there is an observable link between the decline of national economies and the growth of the use of Christian ministry as a channel for economic survival (Biri \& Togarasei 2013; Chitando 2013; Chitando et al. 2013; Maxwell 1998; Togarasei 2011; Vengeyi 2011). ${ }^{1}$ This poses a number of implications, foremost being that church spaces, spiritual conversions, certain spiritual disciplines, membership into certain churches and submission to the leadership of certain prophets and pastors are now considered as steps towards economic emancipation and prosperity. However, it is also noted that many prophets and pastors prescribe on their followers'

1.For a further discussion on the link between the growth of the prosperity gospel and socio-economic decline elsewhere in Africa, see Marshall (2009:167, 181-182) and Gifford (1993:146-189; 1998). 
steps out of poverty that include practices such as 'seeding' - the giving of huge amounts of monetary and property gifts to pastors and prophets as a form of planting seeds in order to reap huge blessings of monetary riches (Angel 2013; Deuschle 2003:74; Hagin 1995:89-113). This has resulted in prophets and pastors accruing huge revenues, which indicates the 'possibility of achieving private wealth through God's work' (Marshall 2009:181). This shows that church spaces and doing ministry now function as spaces of generating and amassing wealth (Marshall 2009:182; Phiri \& Maxwell 2007:23).

Therefore, when it comes to the minister's economic welfare, there is a strong conflict between the traditional view of ministry as a sacrificial act and the prosperity Pentecostal entrepreneurial view of ministry as means of economic prosperity. However, biblical teachings and biblical examples show ministers as having a right to economic survival from their ministry work. At the same time, biblical teachings and examples forbid turning ministry into a channel of amassing wealth. Yet, the Christian minister is essential in empowering Christians to respond to poverty meaningfully. Given the Zimbabwean context that is riddled with endemic, systemic and intergenerational poverty, theological education must be transformed to empower ministers to play an economic role that empowers Christians to engage poverty meaningfully. The article begins by examining the traditional missionary model of ministry as a sacrificial act. Attention is further given to how the African clergy responded to working under the traditional model of ministry as a sacrificial act. This is followed by the examination of the development of the view of ministry as a means of economic prosperity. The article closes by considering the implications of theological education in the African continent riddled with poverty, particularly Zimbabwe.

\section{Ministry as a sacrificial act and Africans' responses to this approach}

Engagement in Christian ministry is traditionally viewed in self-sacrificial terms that project ministry as a difficult, costly and materially unrewarding vocation. Traditionally, ministry did not attract people who expected financially lucrative careers. Beidelman (1981:83) points out that missionaries 'often described their work as an act of sacrifice or as means of refining character'. This description can be seen in many missionaries who endured many personal struggles in the mission field (Ransford 1968:137; Isichei 1995:77-78; Hastings 1994:260), persevered in the midst of uninspiring results (Lovett 1899:625) and faced death and being buried away from their immediate relatives (Thomas 1873:321-323). An important element in the description was the absence of material gain and the rendering of services to desperate people at a cost borne by the servant. Missionaries in African, particularly those in rural areas, mostly served poor people who could only receive more than they could pay back. Thus, venturing into the unknown 'dark lands of Africa' ${ }^{2}$ was viewed in heroic terms (Isichei 1995:77). Lovett summarises

2.Hastings (1994:299-300) explains that the notion of "dark Africa. had several connotations to it that included the Europeans' limited knowledge about the
continent as a whole, the absence of indications of civilization, its experience of continent as a whole, the absence of indications of civilization, its experience of
crimes of slave trade, the absence of Christian belief and its dark-skinned citizens. the challenges faced by the pioneer missionaries in Zimbabwe as: 'The missionaries found the work very difficult, and the prospect uninspiring' (1899:625). Lovett's summary is corroborated by Isichei's (1995) recording of the exasperations of a Catholic missionary who moaned:

One can hardly understand the trouble one experiences, arriving in a savage land, unknown and inhospitable, and being there without what one could call a home - one can't understand what I'm saying, unless one has been there. A thousand worries and a thousand anxieties pursue one daily. No bread, no wine, no eggs. (p. 78)

In the recorded words, it is highlighted that the missionary work in Africa involved many personal sacrifices and deprivations. However, the mournful statement is not necessarily limited to the idea that mission work was undertaken begrudgingly as a hard sentence upon one's life. Rather, whether missionary work was undertaken as an exploration or as a fulfilment of hopes and dreams, or a form of escaping the rapid modernisation and industrialisation of European lands, mission work remained riddled with huge personal sacrifices. ${ }^{3}$

Furthermore, the idea of missionary work as an act of sacrifice and of refining character emphasises that missionaries did not consider their work as a means of economic enrichment, although they did expect to economically survive from it. In fact, mission was a forsaking of the world and undertaking a vocation prompted by frugality and altruism to save and serve lost humanity. Beidelman (1981) shows the Christian Missionary Society (CMS) in Tanzania imposing the following instruction on the missionaries within the society:

Missionary service should be regarded, not as a profession, but as a vocation. It is to be the one thing of life. Everything else is subsidiary. Rest, change, exercise, and relaxation are, of course, necessary for bodily and mental health, but the faithful missionary will employ these solely as recreation, the better to fit him for his Master's service. He will watch lest they ever usurp a place to which they have no right. Even the study of nature or art, the love of exploration, the society of fellow countrymen have been to some a very real cause of danger. (p. 76)

The requirement to treat mission service as a vocation and not a profession emphasised the high degree of commitment and sacrifice that accompanied it. Missionary work did not have material benefits of economic enrichment, but a life of austerity and altruism. Rather than an accruing of material wealth and self-aggrandisement, it was marked with survival with the barest minimum of resources. Furthermore, it was in order to serve and save lost humankind that missionary service was to be considered a calling and not as a job. Therefore, most missionaries adopted an anti-materialistic approach to life by 'living altruistically on meagre incomes'

3.As Beidelman (1981) puts it, with reference to CMS missionaries: As part of their seriousness, their quest for a godly life, the CMS repeatedly expressed an intense seriousness, their quest for a godly life, the CMS repeatedly expressed an intense dislike of materialism. Radical antimaterialism drove these people away from a Britain undergoing rapid industrialization and secularization. Despairing of an ungodly society at home, they sought to construct a new Jerusalem abroad which childlike natives, uncontaminated and undistracted by the myriad products of complex modern society, could live in Christian communities which echoed an image of a Christian past that probably never existed. The Evangelicals were visionary and atavistic at the same time' (p. 78). 
(Beidelman 1981:89). While such a solemn view of ministry galvanised missionaries into treasuring their calling by affirming its solemnity and uniqueness from other professions, in reality it was an expression of privatised faith based on a dualistic view of reality. It dualistically distinguished between worldly things and spiritual things and hence projected material things as secular to the point of lacking God and spiritual things as godly. It gave the impression that faith was useful in a privatised context detached from material things and had no integrated approach between spiritual and material things.

Ironically, while demonstrating being anti-materialistic, the missionaries nonetheless operated as 'mediators of change' (Porter 2004:279), bringing socio-economic transformation in undeveloped Africa (Bourdillon 1983; Hastings 1994:258). The acceptance of meagre incomes was premised on a deep dependence on God's providence - that God was responsible for the welfare of the missionaries and that he would indeed faithfully fulfil his responsibility to the missionary. Furthermore, it does seem that while such missionaries did expect to survive from the ministerial work, this was not so much a primary concern as giving service to a needy world.

Traditional Pentecostalism originally began in Azusa Street as an anti-materialistic movement hungry for God only. Churches like the Apostolic Faith Mission of South Africa and Nicholas Bhengu's South African Assemblies of God 'preached a doctrine of holiness that made them highly sectarian, rejecting the many pleasures and luxuries of everyday life' (Maxwell 2006:9). Marshall-Fratani (1998:282) highlights that the older established Pentecostal churches emphasised a doctrine of 'holiness' and anti-materialism. Furthermore, undertaking ministry was undergirded by faith in God's ability to provide all that the minister needed materially.

The sacrificial view of Christian ministry, tended to be applied on Africans without paying attention to the economic disparity between white missionaries and the African ministers. As an illustration, Gondongwe (2011a:7-14) records Methodist Church authorities in Zimbabwe expressing extreme dismay that young African Methodists shunned the call of ministry on grounds of low pay. One Methodist superintendent is recorded by Gondongwe giving his horrified perspective at the Africans' rejection of the call to ministry stating: 'The whole argument ranged round money. There may be other reasons but I am led to the conclusion that the African expects his job to pay'. This statement conveys the idea that it is wrong to expect economic survival from one's ministry job. To some extent, the expectation of regular income is considered a sign of unwillingness to sacrificially serve and also a lack of dependence and faith in God. Furthermore, an expectation of economic survival seemed a form of materialism. And yet what appeared a sacrificial act to the missionaries, appeared a luxurious act to the poor Africans (Beidelman 1981:89; Gondongwe 2011a:13; Oliver 1952:242).

\section{The shift from ministry as a sacrificial act to economic prosperity in Africa}

The notable shift in Africa from the notion of ministry as a sacrificial act and to the view of Christian ministry as a means of economic prosperity is linked to the rise and growth of prosperity gospel in the continent. The rise and growth of prosperity Pentecostalism are marked by a rejection of the notion of ministry as a sacrificial act and an affirmation of ministry as a blessed profession that must have immediate lucrative benefits for its workers (Marshall 2009:182). Rather than a renunciation of the world, the entrepreneurial movement emphasises taking hold of the world. Rather than a denial of self and an emphasis on austerity, the modern movement emphasises self-indulgence and luxury by propagating a 'doctrine of morally-controlled materialism, in which personal wealth and success is interpreted as the evidence of God's blessing on those who lead a "true life in Christ"' (Marshall-Fratani 1998:282-283). In the traditional movements, one entered ministry for what one could lose in the material now but gain later in multiplied form in the coming glorious heavenly future. Ministry in the entrepreneurial movement is entered for what one can gain now and supposedly carry into the next heavenly life.

Ironically, in some situations, the greatest shift has not been the appearance of new movements but the transformation of the traditional movements from their anti-materialistic holiness orientation to this worldly materialistic orientation. A fitting example shown by Maxwell (2006:151) is the Zimbabwe Assemblies of God Africa (ZAOGA). Maxwell shows that in the 1970s, evangelism was the 'consuming passion' of the pastorate in ZAOGA but, in the 1990s, the primary concern of the pastors was 'related to their material well-being'. The anti-materialist foundation was discarded and replaced by a materialist one. Maxwell further highlights that ZAOGA's Archbishop Ezekiel Guti moved from his earlier emphatic rejection of the doctrine of prosperity by emphasising the relevance of suffering in Christian character formation, and later began to proclaim the 'gospel of money'. The Archbishop is recorded warning the church's pastors in 1997:

If you don't want to die or leave and get poor, or have little kids mock you in the streets, then stay and grow rich. People who have left do not prosper, they lose their blessings. When they get old they have nothing. It takes time to build a church and to start making money. (p. 154)

This message communicated the idea that Christian ministry, in this particular case doing Christian ministry within ZAOGA, guaranteed one economic prosperity. Furthermore, the Archbishop presented himself (or his ministry) as a mediator of God's blessings of economic prosperity. Therefore, those who deserted ministry in ZAOGA were placing themselves outside the ambit of attaining material blessedness. In clear terms, the Archbishop presented himself as having special powers to ensure his congregants' personal security from poverty. This effectively meant that joining ZAOGA's pastoral ministry was not just serving God and 
saving the lost sinners; it was a means towards economic prosperity. In fact, according to Maxwell (2006:160), in the mid-1980s Archbishop Guti had proclaimed to his church that included in his ministry was the blessing of the poor uplifting them from the ashes and polishing them to enhance their acceptability in the country. However, although Guti is reported to have lately criticised the prosperity gospel (The Herald 2013), he continues to operate more or less like other prosperity figures (Biri 2012).

With the shift from 'ministry as service' to 'ministry as entrepreneurship', the church 'can easily $[b e]$ mistake $[n]$... for any successful business enterprise' (Togarasei 2005:358). In fact, one does not need to look deeper to see that churches have become business enterprises that adopt modern business marketing strategies. Interestingly, in Zimbabwe on the leading prosperity prophets, Prophet Walter Magaya was recently controversially recognised as a Zimbabwe's tourism ambassador, because his ministry activities attracted many foreign visits (The Standard 2017).

As Marshall (2009:181-182) highlights, establishing a church and 'doing God's work' have become a means of accumulating of personal wealth and personal dominion. Doing God's work is now approached from the stand point of a 'brand' marketed through the medium of various paraphernalia such as television adverts that can comparatively compete with some adverts of commercial goods, branded armbands, tee-shirts, bottled water and flashy billboards along the major urban highways bearing the colourful pictures of the church leader with his wife. This is aptly demonstrated by the increasing use of 'ministry' to refer to the emerging churches. It is as if traditional churches are not ministry work and 'ministry work' is not church work. Marshall adds:

In a marked departure from mainline Protestant and older Pentecostal churches, the model of church organization came increasingly to resemble that of small (or large) private enterprise, and an internal economy developed based on shared faith and new networks. Church activities proper were joined by subsidiary revenue-generating activities: the sale of media productions for the most part, but in the largest ministries, Bible colleges, private universities, banks, medical clinics, and on-line subscriptions. Approximately 80 per cent of the churches and ministries founded thought the late 1980s and 1990s have become de facto the private property of their founder-leaders. (p. 182)

In this entrepreneurial model of doing church, the founder prophet or pastor functions as a CEO or a president of a personal company. In this church model, the founder leaders stand as the ambassador of their 'brand' model. Consequently, any criticism of the 'ministry' or its anointed leader is met with serious backlash because it is ultimately an attack on the brand. It can be noticed that church leaders adhering to the entrepreneurial model of doing ministry follow an oligarchical style of leadership that logically reduces congregants to the leaders' commoditises while leaving the leaders accountable to no one else but only themselves (Banda 2016:163; Banda \& Senokoane 2009:220; Biri 2012:2; Maxwell 2006:107,134; Togarasei 2005:360). That ministry is being used as a means of economic prosperity is demonstrated in the personalisation of the churches by registering them as private companies owned by the founders (Togarasei 2011:341). Therefore, the leadership succession plan is commonly oriented around the close relatives of the founding leader.

At the centre of the idea of doing ministry as means of economic prosperity is the mediating power of the pastor acting as God's conduit of blessings to the Christian believer. The point is boldly asserted by Prophet Urbert Angel, a Zimbabwean leading proponent of this gospel. Angel commands Christians who aspire for wealth to generously plant their seed for a good harvest on fertile ground by magnanimously giving their money to 'anointed' pastors $(2013: 15,60,87,89)$. Angel believes that the key to unlocking the blessing of riches is not in giving to the poor or offering and tithing in church. Rather, the key to wealth lies in giving to the people anointed by God, particularly the: 'Men of God with great anointing' (Angel 2013:87). To Prophet Angel, the widow of Zarephath (1 Ki 17:7-24) was saved from nearly starving to death because she emptied her last food reserves on the prophet of God, Elijah. Prophet Angel asserts the mediating power of the prophets by commanding believers to first check the level of anointing in the pastor they want to give to. Angel (2013) instructs that givers must ask the following questions about the prophets they want to give their 'seeds' to:

What do they have? Do they have plenty or less? What achievements do they possess? What is the impact they have made on earth? (p. 87)

According to this model, the pastors who have less are not fertile ground for wealth seeking Christians to plant in. In this model, ministry has shifted from the sacrificial rendering of service to making an investment whose yields must be harvested immediately in this life. Thus, ministry has become a channel of accumulation of wealth. From the above discussion, the emerging question concerns the relationship between doing ministry and the economic benefits accrued to the minister.

\section{Ministry as a means of economic survival: Greed or gospel power?}

Despite its damaging excesses, prosperity Pentecostalism has challenged the traditional view that makes it appear shameful and unministerial for Christian ministers to expect economic survival from their ministerial work. It has further challenged the idea that ministers should survive on charity and donations from overseas. Zimbabwe's Pastor Tom Deuschle in his Building People, Building Dreams: How a Church Can Change a Nation (2003) usefully presents an entrepreneurial perspective of the church as a place of engendering a culture of entrepreneurship and management of economic resources. Furthermore, the prosperity model has de-paganised money and wealth by affirming them as economic things that God has given to his people for use in this world, and therefore 
challenged the tendency to demonise wealth and the unnecessary suspicion cast on rich people.

However, underlying the notion of ministry as a means of economic prosperity is the confusion between clientelism and discipleship (Maxwell \& Phiri 2007:23). Considering the amount of money that the Christians end up leaving at the end of the various meetings and services, it raises questions as to whether these meetings are intended to produce Christ-like disciples or to bolster the prosperity pastors' clientele base (Marshall 1992:16). The end result is the 'sacralising greed and covetousness' (Asamoah-Gyadu 2009:41) as each pastor seeks to brazenly bolster their clientele base. The idea of ministry as a means of economic prosperity has revived the superstitious tendencies of Medieval Roman Catholicism that promoted the use of the gospel and ministry as means of self-enrichment by the corrupted church that was vehemently condemned by the Reformer John Calvin (Institutes 4.5.16-18). Listening to the Reformers' blistering condemnation of the corruption and abuse of the Christians by the Medieval Church suggests that they would have issued the same condemnation to the modern use of the gospel as a channel of economic enrichment.

\section{Theological education and the ministers' approach to economic life in Zimbabwe}

It can be argued that the ministry expression of a Christian leader reflects his or her theology. One's theological understanding and education can hardly be separated from one's practice. Theory (theological understanding) influences praxis (ministry practice). This section reflects on the interplay between theology and praxis in Zimbabwe.

\section{The economic deficiencies in the traditional approach to theological education}

It is argued that theological education in the traditional approach to Christian ministry as a sacrificial act, particularly in some mainline Protestant circles, tends to prioritise horizontal piety and lacks a thorough application to political and economic life (Amanze 2008:4). Gondongwe has already showed that the African ministers in the Methodist Church in Zimbabwe were poorly paid and yet barred from undertaking personal businesses to supplement their meagre incomes and sometimes even went many years without receiving a stipend (Gondongwe 2011a:13). Research is needed to establish how those African ministers preached about money, wealth and economic issues and the nature of the economic advice they gave to their inquiring congregates. Theological education in such cases appears to have only prepared ministers for evangelistic purposes and not a holistic life that included economic participation and engagement (Gondongwe 2011b:83). The curriculum in traditional theological education in Zimbabwe has generally lacked economic and entrepreneurial literacy (Amanze 2008:9-11; Gondongwe 2011b:90, 103) even though it may have increased consciousness for social and political justice (Matikiti 2009:157). Although the traditional theological education system produced critical thinkers like Esau Nemapare, Thomas Samkange (Ranger 1995:8-9, 16), Mathew Rusike (Gondongwe 2011a:17-19) and later Ndabaningi Sithole, Abel Muzorewa and Canaan Banana who challenged the oppressive colonial system and called for economic justice (Ranger 1995:16), their political thought has not translated into a visible and viable ethics of economic life for church ministers. There is a serious gap between spirituality and economic life.

However, even theological education and religious studies in modern public universities tends to remain highly theoretical without sufficient entrepreneurial grounding (Chitando 2010:197). Indeed, theology and religion have positively contributed to the decolonisation of Africa, fighting gender inequality and HIV and AIDS, yet they remain trapped into focusing on abstract and historical issues with little or no relevance to contemporary socioeconomic and political situations (Chitando 2010:202-204). This can be attributed to theological training that is detached from community involvement (Chitando 2010:204). He further finds that most theological teaching in Africa is conducted in 'a largely non-contextual manner', which means that important theological truths that could have a significant empowering effect remain abstract. In other words, important theological truths do not percolate to the market place. It is a serious scandal that many African pastors would vociferously preach that God commanded human beings to rule over the earth (Gn 1:28) and yet never realise the entrepreneurial implications imposed by this command upon them. In her journal entry on the 7th of May, 1900, Sister Bullen (2008), a Catholic missionary to the Ndebele people in Empandeni, recorded the following conversation among the local people:

Some natives were heard talking about God the other day: He was stingy when He made them for he gave them no clothes and did not teach them how to make them. He gave them not money and did not tell them how to earn it. But He was generous when He made the white people for they have everything and can do everything. (p. 56)

A theological education that is entrepreneurially grounded can help many poor Zimbabweans to realise their 'God given potential' (Speckman 2007:xvii, 1) by which they can transform their poor economic condition. Zwana rightly observes that: 'The shift in Christianity's centre of gravity to the South has not been matched by a sustained reconstructive discourse promoting authentic African Christian epistemologies' (2007:79). In this, he challenges Christian theology to be transformatively relevant to the lived struggles of African indigenous communities. 


\section{The de-economisation of socio-economic reality in prosperity pentecostalism}

The term 'de-economisation' is referred to the tendency of disconnecting the reality of poverty from its prevailing socioeconomic and political context, which can also be described as de-politicisation or de-historicisation (Banda 2016:167). This is a common approach to economic life in prosperity Pentecostalism where poverty is attributed to spiritual forces in a way that undermines and overlooks the socio-political and economic context (Angel \& Angel 2014: 2nd, 21st January 2014). This de-economised approach to economic survival and prosperity translates into a theological education system that seriously cripples the potential of the Christian minister to be a meaningful channel of economic survival. It does not give the minister the tools to attend to the socio-economic and politics that foster poverty. For illustrative purpose, Bishop Tudor Bismark's Jabula New Life Ministries International, in Harare, runs the New Life Bible Institute (2014) and offers a 3-year ministry training programme. Out of a complement of 34 courses only four courses, Gender Studies (first year, second semester), Strategic Management (second year, second semester), Principles of Leadership and Management (third year, first semester) and Creating Generational Wealth (third year, second semester), have economic relevance. Rhema Ministries in South Africa headed by Pastor Ray McCauley runs Rhema Bible College (2012) that has a Business School under its short courses that conducts classes on Saturdays offering courses such as Business Plan, Budgeting and Cash Flow, Managing Money/ Finding your Business, Efficient Operations and Production among many other business courses. These business courses suggest a serious commitment of engendering a culture of entrepreneurship among its members. However, disappointingly, the business module is not included in the 3-year ministry training programme, where economic issues are perhaps dealt with under the Redemptive Realities module which covers three topics: Breaking free, Christ the healer and Stewardship. This means that those training for the ministry are not exposed to economic principles needed for economic survival. This gives an impression that ministers do not need to grasp the economic, social and political dynamics that create poverty. It appears that ministers only need to exercise Principles of Faith, deal with Generational Curses and exercise Kingdom Principles in order to survive economically.

\section{An emphasis on the mediatory role of prophets that undermines human agency}

As is observable among many prosperity Pentecostal churches is the rise of the utilisation of church spaces as areas for generating wealth and also of healing. The common result of this is that the prophets' headquarters has shrine status to which all the prophet's ministry activities must be connected. While this system keeps the movement interconnected, the emerging system of theological education advances the interests of the headquarters by entrenching the supremacy of the pastor who holds the power to bless and is also the carrier of the vision of the movement. While it is true that prosperity Pentecostal churches do indeed emphasise entrepreneurship among their members and even offer entrepreneurial seminars to help their members with needed knowledge to set up successful businesses (Chitando 2013; Deuschle 2003:69-100; Rhema Ministries 2012; Togarasei 2011:342-348), the prophets impose a mediatory role that ultimately undermines the very personal human efforts fostered in the entrepreneurial seminars. For instance, both Hagin's Biblical Keys to Financial Prosperity (1995) and Angel's God's Get Rich Quick Scheme (2013) lay such an emphasis on giving to the pastor but silent on a theology of work as means towards economic prosperity. Quite often, the theology of wealth and poverty diminishes a critical theological reflection and emphasises direct communication with God in a way that 'absolve[s] human beings of their responsibility in creating the crisis as well as their role in its resolution' (Chitando \& Manyonganise 2011:101). This approach leaves prosperity Pentecostals susceptible to the charge that the deliberately employ mediocre theological reflection that only advances their self-interests.

\section{The Bible on economic survival in Christian ministry and its implications on theological education}

What then should theological education be and do in order to foster a system of economic survival from Christian ministry that is God-honouring manner that does not abuse God's people, but enables Christian ministers to be productive economic participants?

\section{The Bible's distinction economic survival and economic prosperity in ministry}

Biblical teachings distinguish between Christian ministry as an instrument used for economic survival and ministry as an instrument of service from which the minister must expect to earn economic survival. There is distinction between selfenrichment out of the ministry and being justly rewarded for being in ministry. A basic principle that runs across the Bible is that people have a right to economically survive from their work, including those in ministry. The Torah stated: 'Do not muzzle an ox while it is treading out the grain' (Dt 25:4). ${ }^{4}$ This principle was applied to the Levite priests to emphasise that the priests should derive an income from their priestly work (Dt 18:1). Jesus observed the principle of not muzzling the ox while treading out the grain in Luke 10:1-24 when he sent out 72 disciples but forbid them from taking any supplies along, telling them to survive from what their hosts will serve to them. Christ's reason for doing this was that 'the 4.Quoted from the New International Version (NIV), throughout, unless stated otherwise. 
worker deserves his wages' (Lk 10:7). The Apostle Paul appealed on these two principles in 1 Corinthians 9 and 1 Timothy 5:18 to affirm the right of the ministers of the gospel to receive economic support from their ministries. Paul defended the right of the ministers to expect and to receive financial support for their ministry work in the church. (1 Cor 9:9-12). Zimmermann points out that the issues presented by Paul in 1 Corinthians 9 are ethical issues concerned with: 'What is right conduct? What is good and correct to do, and why?' (2012:2). This body of evidence from biblical command and observable situations in life show that it is ethically right for those who have taken up the work of the ministry to receive material support (Fee 2014:457; Zimmermann 2012:2). For Paul, material welfare was important, but not important enough to hinder ministry. Here Paul's conduct means that:

The key to everything must be for us what it was for Paul - 'nor hindrance to the gospel'. For every valid ministry in the church of Jesus Christ this must be the bottom of line. All too often, one fears, the objective of this text is lost in concerns over 'rights' that reflect bald professionalism rather than a concern for the gospel itself. (p. 457)

However, in the midst of absence of material support from the congregation, Paul's option was not resignation to poverty. Rather, since ministry was of supreme priority, he used his extra economic skills to earn his material welfare. Hence he could boldly say to the Christians: 'You yourselves know that these hands of mine have supplied my own needs and the needs of my companions' (Ac 20:34). For Paul, the commitment to the gospel, not money, dictated and shaped his ministerial ethics and practice. Therefore, Paul shows us a minister who benefits from his ministerial work and not one who seeks to profiteer out of ministry.

It can be concluded that the Bible does not regard ministry as an instrument for economic gain. This means that involvement in ministry should not be prompted by financial or material gain, but by service that transforms and heals the broken world (Oliver 2016:1). Yet on the contrary, those who choose the work of Christian ministry have a right to expect economic survival from it. Consequently, there are biblical warnings about those false teachers how teach false gospel 'for the sake of dishonest gain' (Tt 1:11). Furthermore, the elders are instructed to be diligent shepherds who are 'not a lover of money' (1 Tm 3:3) and 'not greedy for money' (1 Pt 5:3). These biblical texts condemn those who enter ministry as a means of financial gain. Jesus solemnly told his disciples that no one can serve God and mammon (Mt 6:24).

A foundational point to ministry as an instrument of service, even to sacrificial extents, is the eschatological nature of Christian ministry. Christian ministry is motivated by the quest for the Kingdom of God which will be fully consummated at the final return of Christ but is already present in this world challenging the death-inflicting kingdom of darkness (Bauckham \& Hart 1999; Conradie 2001; Harvie 2009; Meeks 1996; Moltmann 1967; 1999; Wright 2007). Christian ministry forbids self-aggrandising materialism because as an eschatological work, the Christian minister works in his world - even to sacrificial levels - with the assurance that there is a better reward to be received at the final consummation of the Kingdom of God.

\section{A theological education that de-commodifies the church}

Therefore, one of the primary tasks of theological education in Zimbabwe is the construction of an ecclesiology that decommodifies the church. It has been noted that there is a problem of the commodification of the church in Zimbabwe, particularly in prosperity Pentecostalism. However, the refusal by former Bishop of the Anglican Church in Zimbabwe, Norbert Kunonga, to vacate his bishopric at the end of his term of office demonstrated that the commodification of the church also happens in traditional mainline churches. Therefore, the commodification of the church should not just be treated as a prosperity Pentecostal problem. A significant problem in the Zimbabwean churches is 'Mugabean' (Chitando, Taringa \& Mapuranga 2014:180) tendencies as church ministers hold onto churches as their personal properties and refuse to vacate when no longer wanted by the congregations.

Theological education in Zimbabwe must, therefore, instil an ecclesiology that de-commodifies the church and instils within Christian ministers that in as much as they must derive economic survival from their churches they must be accountable to the churches they lead. This requires a concerted awareness that the church is not a personal commodity, it belongs to Christ, and the minister is not really the head of the church but is a steward over God's people and is thus accountable to Christ as the head of the church (Eph 1:22; 5:23). This means that ministers must not manipulate Christ's people for their own selfish ends. This requires not only an awareness of what the church is but also a view of church leadership that is grounded in the interplay between spirituality and ethical formation (Kretzschmar 1997; 2002; Naidoo 2013).

\section{A theological education that instils a sound theology of work}

A major challenge in Zimbabwe, and most of Africa, is a poor theology of work that often contributes to poor initiative, poor workmanship and poor deployment of resources (Chitando 2010:198-199; Van Rooy 1999:237). An essential aspect that needs to be challenged in the Zimbabwean context is the worldview of work, where work is seen as just a means of survival instead of an expression of the God-given creative potential. German theologian H. Bedford-Strohm emphasises that poverty be viewed as 'a lack of participation' (2008:157), which means that meaningful ways of addressing poverty are not through charity, but equipping with a means for viable participation. South African bible scholar McGlory Speckman (2007) reflects on the disciples' healing of the crippled man instead of giving him alms (Ac 3:1-10), and argues for a biblical vision of development that goes beyond giving crutches and wheelchairs (charity) to the provision of 
"'sturdy legs" for destitute communities to stand on' (2007:xxvi-xxvii). Chitando (2010:199) rightly likens Africa to the man in John 5:1-9 who was ill for 38 years but stationed right next to the healing waters and says Africa lies on top of and right next to riches that can transform it. Theological education is, therefore, challenged to instil a sound liberating and empowering theology of work to enable the poor to be productive citizens (Myers 2011:3-4). This calls for theological education that unlocks a sound theology of work. On the characteristics of being created in the image of God is the ability to be creative, which means that work is not only for survival's sake but also an expression of being in the image of God (Moltmann 1984:40).

A good theology of work must be accompanied by economic literacy. This requires that theological education open the ministers to the socio-economic and political dynamics that foster African's endemic intergenerational poverty. Such theological education will equip ministers to enhance the human agency of their communities. This means that theological education must be contextualised into the Zimbabwean realities in order to transform them. The implications of this are that theological curricula cannot be abstract but must deal with real contextual issues (Chitando 2010:205-208; Haddad 2016; Oliver 2016). While this is somewhat beginning to happen in Zimbabwe, ${ }^{5}$ it is insufficient because a significant portion of religious studies in Zimbabwe are conducted from a phenomenological perspective, which often does not ground students in the socio-economic and political implications of Christian doctrines. In a context of poverty in Zimbabwe, theological education must be conducted from an entrepreneurial and developmental perspective. Further research must, therefore, be done to establish how such a theological curriculum should look.

\section{Conclusion}

This article has attempted to affirm that theological education and Christian ministry are indeed means for honest economic survival and not a means for economic prosperity and self-aggrandisement. That is, in choosing the vocation of Christian ministry, the ministers derive their welfare and support from their work. Furthermore, theological education must equip and empower Christian ministers to be productive economic participants in their communities. It further highlighted steps that ought to be taken in theological education in order to empower ministers as just and effective economic participants. Christian ministers must do everything possible to increase their economic and political literacy so that they can be agents of social transformation in their churches. Rather than merely expect economic survival from their churches, they should empower and equip their congregants economically. Pastors must not take advantage of the church by using it as a channel of amassing personal wealth. 5.For example, the Midlands State University now prescribes a module
Entrepreneurship on all its undergraduate students, including theology and religious students.

\section{Acknowledgements}

This work is based on research supported by the University of Zululand, South Africa and the South African National Research Foundation (NRF). Any opinion, finding and conclusion or recommendation expressed in this material is that of the author(s) and the NRF does not accept any liability in regard thereto.

\section{Competing interests}

The authors declare that they have no financial or personal relationships which may have inappropriately influenced them in writing this article.

\section{Authors' contributions}

V.M. and C.B. equally contributed to the research and writing of this article.

\section{References}

Amanze, J.N., 2008, Paradigm shift in theological education in southern and central Africa and its relevance to ministerial formation, viewed 06 February 2017, from https://www.oikoumene.org/en/folder/documents-pdf/WOCATI_2008_-Presentation_of_ATISCA_Prof._Amanze.pdf

Angel, U., 2013, God's get rich quick scheme: Secrets to the quickest way of getting rich God's way, Spirit Library, N.P., Singapore.

Angel, U. \& Angel, B., 2014, Power for today: Jump-starting your day: Daily devotional, vol. 5, Spirit Library, N.P., Singapore

Asamoah-Gyadu, K.J., 2009, 'Did Jesus wear designer robes? The gospel preached in Africa's new Pentecostal churches ends up leaving the poor more impoverished than ever', Christianity Today 53(11), 38-41.

Banda, C., 2016, 'Empowering hope? Jürgen Moltmann's eschatological challenge to ecclesiological responses in the Zimbabwean context of poverty', Unpublished $\mathrm{PhD}$ thesis, University, Stellenbosch.

Banda, C. \& Senokoane, B.B., 2009, 'The interplay between the Christian sacralization of human authority and political repression in Zimbabwe', Religion \& Theology 16 207-245. https://doi.org/10.1163/102308009X12561890523636

Bauckham, R. \& Hart, T., 1999, Hope against hope: Christian eschatology at the turn of the millennium, W.B. Eerdmans, Grand Rapids, MI.

Bedford-Strohm, H., 2008, 'Poverty and public theology: Advocacy of the church in pluralistic society', International Journal of Public Theology 2(2), 144-162. https:// doi.org/10.1163/156973208X290017

Beidelman, T.O., 1981, 'Contradictions between the sacred and the secular life: the church missionary society in Ukaguru, Tanzania, East Africa, 1876-1914" Comparative Studies in Society and History 23(1), 73-95. https://doi.org/10.1017/ S0010417500009695

Biri, K., 2012, 'The silent echoing voice: Aspects of Zimbabwean Pentecostalism and the quest for power, healing and miracles', viewed 03 April 2014, from http://uir. unisa.ac.za/handle/10500/6609

Biri, K. \& Togarasei, L., 2013. “.... but the one who prophesies, builds the church” Nation building and transformation discourse as true prophecy: The case of Zimbabwean Pentecostal women', in E. Chitando, M.R. Gunda \& J. Kügler, (eds.), Prophets, profits and the Bible in Zimbabwe: Festschrift for Aynos Masotcha Moyo, pp. 79-94, University of Bamberg, Bamberg.

Bourdillon, M.F.C., 1983, 'Christianity and wealth in rural communities in Zimbabwe', Zambezia 19, 38-53.

Bullen, J., 2008, Empandeni interlude, 1899-1903: journal of a woman missionary Josephine Bullen, SND de Namur, at the turn of the century in Rhodesia, Cluster, Pietermaritzburg.

Chitando, E., 2010, 'Equipped and ready to serve? Transforming theology and religious studies in Africa', Missionalia 38(2), 197-210.

Chitando, E., 2013, 'Prophets, profits and protests: Prosperity theology and Zimbabwean gospel music', in E. Chitando, M.R. Gunda \& J. Kügler (eds.), Prophets, profits and the Bible in Zimbabwe: Festschrift for Aynos Masotcha Moyo, pp. 95-112, University of Bamberg, Bamberg.

Chitando, E, Gunda, M.R. \& Kügler, J., 2013, Prophets, Profits and the Bible in Zimbabwe: Festschrift for Aynos Masotcha Moyo, University of Bamberg, Bamberg.

Chitando, E. \& Manyonganise, M., 2011, 'Voices from faith-based communities', in T. Murithi \& A. Mawadza (eds.), Zimbabwe in transition: A view from within, pp. 77-111, The Institute of Justice and Reconciliation, Pretoria.

Chitando, E., Taringa, N.T. \& Mapuranga, T.P., 2014, 'Zimbabwean theology and religious studies during the crisis years (2000-2008): A preliminary study', Studia Historiae Ecclesiasticae 40(1), 173-189. 
Conradie, E.M., 2001, 'Eschatological dimensions of a "Theology of Life", in A. Van Egmond \& D. Van Keulen (eds.), In Christian hope in context, pp. 163-204, Meinema, Zoetermeet.

Deuschle, T., 2003, Building people, building dreams: How a church can change a nation, Hear the Word, Harare.

Fee, G.D., 2014, The first epistle to the Corinthians (Revised Edition), Wm. B. Eerdmans, Grand Rapids, MI.

Gifford, P., 1993, Christianity and politics in Doe's Liberia, Cambridge University, Cambridge.

Gifford, P., 1998, African Christianity: Its public role, C. Hurst, London.

Gondongwe, K., 2011a, “"Garden boys receive better pay plus ration than us": The case of Zimbabwean Wesleyan Methodist Indigenous clergy and the development of resistance to domination, 1950-1977', Studia Historiae Ecclesiasticae 37(2), $1-28$.

Gondongwe, K., 2011b, 'African ministers and the emergence of resistance to colonial domination: The development of indigenous clergy in the Wesleyan Methodist Church in Zimbabwe from 1891 to 1980', Unpublished PhD thesis, University of KwaZulu/Natal, Pietermaritzburg.

Haddad, B., 2016, 'Curriculum design in theology and development: Human agency and the prophetic role of the church', HTS Teologiese Studies/Theological Studies 72(4), 1-8. https://doi.org/10.4102/hts.v72i4.3432

Hagin, K.E., 1995, Biblical keys to financial prosperity, Kenneth Hagin Ministries, Tulsa, OK.

Harrell, D.E., 1975, All things are possible: The healing \& charismatic revivals in modern America, Indiana University, Bloomington, IN.

Harvie, T., 2009, Jürgen Moltmann's ethics of hope: Eschatological possibilities for moral action, Ashgate, Surrey.

Hastings, A., 1994, The church in Africa: 1450-1950, Clarendon, Oxford.

Isichei, E.A., 1995, A history of Christianity in Africa: From antiquity to the present W.B. Eerdmans, Grand Rapids, MI.

Kretzschmar, L., 1997, 'The gap between belief and action: Why is it that Christians do not practise what they preach?', Scriptura 62, 311-321. https://doi. org/10.7833/62-0-624

Kretzschmar, L., 2002, 'Authentic Christian leadership and spiritual formation in Africa', Journal of theology for Southern Africa 113, 41-60.

Lovett, R., 1899, The history of the London Missionary Society: 1795-1895, vol. 1, Henry Frowde, London.

Marshall, R., 1992, 'Pentecostalism in Southern Nigeria: An overview', in P. Gifford (ed.), New dimensions in African Christianity, pp. 7-32, AACC, Nairobi.

Marshall, R., 2009, Political spiritualties: The pentecostal revolution in Nigeria, University of Chicago, Chicago, IL.

Marshall-Fratani, R., 1998, 'Mediating the global and local in Nigerian pentecostalism', Journal of Religion in Africa 28(3), 278-315. https://doi.org/10.1163/157006698X 00035

Matikiti, R., 2009, United Theological College: A centre for ecumenical education in Zimbabwe? Studia Historiae Ecclesiasticae 35, Supplement, 153-166, viewed 24 November 2015, from http://www.scielo.org.za/pdf/she/v35s1/02.pdf

Maxwell, D., 1998, “'Delivered from the spirit of poverty?": Pentecostalism, prosperity and modernity in Zimbabwe', Journal of Religion in Africa 28(3), 350-373.

Maxwell, D., 2006, African gifts of the spirit: Pentecostalism \& the rise of a Zimbabwean transnational religious movement, Weaver, Harare.

Maxwell, J. \& Phiri, I., 2007, 'Gospel riches: Africa's rapid embrace of prosperity Pentecostalism provokes concern and hope', Christianity Today 51(7), 22-29.

Meeks, D.M., 1996, 'The future of theology in a commodity society', in M. Volf, C. Krieg \& T. Kucharz (eds.), The future of theology in a commodity society. In the future of theology: Essays in honour of Jürgen Moltmann, pp. 253-266, W.B. Eerdmans, Grand Rapids, MI.

Moltmann, J., 1967, Theology of hope: On the $g$ round and the implications of a Christian eschatology, Fortress, Minneapolis, MN.
Moltmann, J., 1984, On human dignity: Political theology and ethics, Fortress, Philadelphia, PA.

Moltmann, J., 1999, God for a secular society: The public relevance of theology, SCM, London.

Myers, B.L., 2011, Walking with the poor: Principles and practices of transformationa development, Revised \& Expanded edn., Orbis, Maryknoll.

Naidoo, M., 2013, 'Persistent issues impacting on the training of ministers in the South African context', Scriptura: International Journal of Bible, Religion and Theology in Southern Africa 112, 1-16.

New Live Covenant Church, 2014, New Life Bible Institute, viewed 21 April 2017, from http://www.jabulanlcc.org/ministries/new-life-bible-institute/

News24, 2015, The churches as a business, viewed 12 February 2017, from http:// www.news24.com/MyNews24/The-churches-as-a-business-20150916

Oliver, E., 2016, 'Theology: Still a queen of science in the post-modern era', In die Skriflig/In Luce Verbi 50(1), 1-7. https://doi.org/10.4102/ids.v50i1.2064

Oliver, R., 1952, The missionary factor in East Africa, Longmans, London.

Phiri, I.P. \& Maxwell, J., 2007. 'Gospel riches - Africa's rapid embrace of prosperity Pentecostalism provokes concern and hope', Christianity Today 51(7), 22-29.

Porter, A.N., 2004, Religion versus empire?: British Protestant missionaries and overseas expansion, 1700-1914, Manchester University, Manchester.

Ranger, T.O., 1995, Are we not also men?: The Samkange family \& African politics in Zimbabwe, 1920-64. Baobab, Harare.

Ransford, O., 1968, The rulers of Rhodesia from earliest times to the referendum, Murray, London.

Rhema Ministries, 2012, Rhema Bible College, viewed 21 April 2017, from http:// www.rhemabiblecollege.co.za/programmes

Speckman, M.T., 2007, A biblical vision for Africa's development?, Cluster, Pietermaritzburg.

The Herald, 2013, 'Archbishop Guti speaks against gospel of prosperity', May 13, viewed 13 July 2015, from http://www.herald.co.zw/archbishop-guti-speaksagainst-gospel-of-prosperity-opposed-to-prayer/

The Herald, 2014, 'World's richest pastors', 16 August, viewed 29 April 2017, from http://www.herald.co.zw/worlds-richest-pastors/

The Standard, 2017, 'Minister lavishes Magaya with praise', 05 February, 2017, viewed 10 February 2017, from https://www.thestandard.co.zw/2017/02/05/ministerlavishes-magaya-praise/

Thomas, T.M., 1873, Eleven years in Central South Africa: A journey into the interior, sketch of recently discovered diamond and gold fields, umzilikazi, his country and people, a brief history of the Zambesi missions, J. Snow, London.

Togarasei, L., 2005, 'Modern Pentecostalism as an urban phenomenon: The case of the Family of God Church in Zimbabwe', Exchange 34(4), 349-375. https://doi. org/10.1163/157254305774851484

Togarasei, L., 2011, 'The Pentecostal gospel of prosperity in African contexts of poverty: An appraisal', Exchange 40, 336-350. https://doi.org/10.1163/ 157254311X600744

Van Rooy, J.A., 1999, 'The Christian gospel as a basis for escape from poverty in Africa', In die Skriflig/In Luce Verbi 33(2), 235-254. https://doi.org/10.4102/ids.v33i2.626

Vengeyi, O., 2011, “'Zimbabwean poverty is man-made!" Demystifying poverty by appealing to the prophetic book of Amos', Scriptura 107, 223-237. https://doi org/10.7833/107-0-138

Wright, N.T., 2007, Surprised by Hope, SPCK, London.

Zimmermann, R., 2012, "Mission versus ethics in 1 Corinthians 9?: 'Implicit ethics' as an aid in analysing New Testament texts", HTS Theological Studies 68(1), 211-219.
http://www.scielo.org.za/scielo.php?script=sci_arttext\&pid=S0259-94222012000 http://wwh 100056

Zwana, S., 2007, 'Church-related universities as a manifestation of new frontiers in mission: The Zimbabwean experience', Missionalia: Southern African Journal of Mission Studies 35(2), 71-88. 